\title{
Efektivitas dan Kontribusi Pajak Hotel dan Pajak Restoran terhadap Penerimaan Pendapatan Asli Daerah (PAD) Kabupaten Jember
}

\author{
(Effectiveness and Contribution of Hotel Tax and Restaurant Tax on Revenue of Original \\ Region of Jember Regency)
}

\author{
Ebtisam Lukman Basyarahil*, Ririn Irmadariyani \\ Jurusan Akuntasi, Fakultas Ekonomi dan Bisnis, Universitas Jember (UNEJ) \\ Jln. Kalimantan 37, Jember 68121 \\ E-mail: basyarahilnon@yahoo.co.id
}

\begin{abstract}
Abstrak
Penelitian ini bertujuan untuk mengetahui efektivitas dan kontribusi pajak hotel dan pajak restoran terhadap penerimaan Pendapatan Asli Daerah (PAD) Kabupaten Jember. Jenis data yang digunakan dalam penelitian ini adalah data sekunder yang terdiri dari data target dan realisasi penerimaan pajak hotel, pajak restoran dan PAD pada tahun 2011 sampai 2015. Metode analisisnya adalah dengan menggunakan analisis deskriptif kuantitatif. Hasil penelitian menunjukkan tingkat efektivitas penerimaan pajak hotel dan pajak restoran Kabupaten Jember selama tahun 2011 sampai 2015 berada dalam kategori sangat efektif karena tingkat efektivitasnya di atas $100 \%$. Hal ini menunjukkan bahwa pemerintah daerah Kabupaten Jember telah berhasil dalam mencapai target penerimaan pajak hotel dan pajak restoran yang telah ditetapkan. Sedangkan kontribusi penerimaan pajak hotel pada tahun 2011 sampai 2015 terhitung kecil terhadap penerimaan Pendapatan Asli Daerah (PAD) Kabupaten Jember karena persentase kontribusi tiap tahunnya kurang dari 20\%. Begitu juga dengan kontribusi penerimaan pajak restoran selama tahun 2011 sampai 2015 terhitung kecil terhadap penerimaan PAD Kabupaten Jember. Hal ini berarti bahwa proporsi dari pajak hotel maupun pajak restoran kecil terhadap penerimaan PAD Kabupaten Jember.
\end{abstract}

Kata Kunci: Efektivitas, Kontribusi, Pajak Hotel, Pajak Restoran, PAD.

\begin{abstract}
This study aims to determine the effectiveness and contribution of hotel tax and restaurant tax on Revenue of Original Region of Jember Regency. The data that used in this research is secondary data which are a data of target and realization of Jember Regency Revenue of Original Region, hotel tax and restaurant tax from year 2011 to 2015. The analysis method used was descriptive quantitative. The results showed that the effectiveness of hotel tax and restaurant tax of Jember Regency during 2011 to 2015 in very effective category because the effectiveness level is above $100 \%$. This indicates that the local government of Jember Regency has succeeded in achieving the target of hotel tax and restaurant tax which has been determined. While the contribution of hotel tax in 2011 to 2015 counted small to the Revenue of Original Region Jember Regency because the percentage of contribution per year is less than $20 \%$. Likewise, the contribution of restaurant tax during 2011 to 2015 is small on the Revenue of Original Region Jember Regency. This means that the proportion of hotel taxes as well as small restaurant taxes on the revenue of PAD Kabupaten Jember.
\end{abstract}

Keywords: Effectiveness, Contribution, Hotel Tax, Restaurant Tax, Revenue of Original Region.

\section{Pendahuluan}

Desentralisasi menurut Undang-Undang Nomor 32 Tahun 2004 merupakan penyerahan wewenang oleh pemerintah kepada daerah otonom untuk mengatur dan mengurus urusan pemerintahan dalam sistem Negara Kesatuan Republik Indonesia. Hal ini berarti pemerintah daerah diberikan otonomi yang luas dan bertanggungjawab untuk mengatur rumah tangganya sendiri. Dengan kewenangan yang luas, salah satu konsekuensinya daerah harus mampu membiayai semua kegiatan pemerintahan dan pembangunan yang menjadi kewenangannya. Untuk itu setiap daerah dituntut untuk selalu berusaha meningkatkan Pendapatan Asli Daerah (PAD).

Peningkatan PAD akan tercapai dengan cara menggali semaksimal mungkin sumber-sumber PAD yang potensial. Pajak daerah merupakan salah satu sumber PAD. Menurut Undang-Undang Nomor 28 Tahun 2009, pajak daerah merupakan kontribusi wajib kepada daerah yang terutang oleh orang pribadi atau badan yang bersifat memaksa berdasarkan undang-undang, dengan tidak mendapatkan imbalan secara langsung dan digunakan untuk keperluan daerah bagi sebesar-besarnya kemakmuran rakyat. Terdapat sebelas jenis pajak yang menjadi pajak kabupaten/kota diantaranya yaitu pajak hotel dan pajak restoran. Dengan menggali, mengelola dan meningkatkan potensi pajak daerah yang ada maka PAD dapat meningkat. Begitu juga dengan Kabupaten Jember untuk dapat meningkatkan pajak daerah yang pada akhirnya akan dapat memaksimalkan PAD maka diharapkan Kabupaten Jember dapat menggali, mengelola dan memaksimalkan potensi yang ada.

Kabupaten Jember merupakan salah satu kabupaten di Jawa Timur. Kabupaten Jember dikenal dengan karnaval peragaan busana yang disebut dengan Jember Fashion Carnafal (JFC). Setiap tahun wisatawan domestik dan mancanegara datang ke Jember untuk menyaksikan JFC. Dengan meningkatnya kunjungan wisatawan ke Jember, investasi di bidang hotel

\footnotetext{
* Corresponding author
} 
dan restoran di Jember semakin meningkat. Pada pelaksanaan JFC 2015 tingkat hunian di Jember naik hampir seratus persen (sumber: www.sindoweekly.com). Selain JFC Kabupaten Jember juga memiliki berbagai wisata yang lain. Hal ini menunjukkan bahwa kabupaten Jember memiliki potensi di sektor pariwisata yang dapat dikembangkan sehingga dapat memberikan kontribusi dalam penerimaan Pajak Hotel dan Pajak Restoran yang akan menambah PAD.

Rumusan masalah dalam penelitian ini yaitu yang pertama bagaimana tingkat efektivitas penerimaan pajak hotel di Kabupaten Jember, kedua bagaimana tingkat efektivitas penerimaan pajak restoran di Kabupaten Jember, ketiga bagaimana kontribusi penerimaan pajak hotel terhadap penerimaan PAD Kabupaten Jember, keempat bagaimana kontribusi penerimaan pajak restoran terhadap penerimaan PAD Kabupaten Jember.

Penelitian ini bertujuan untuk mengetahui tingkat efektifitas penerimaan pajak hotel di Kabupaten Jember, untuk mengetahui tingkat efektifitas penerimaan pajak restoran di Kabupaten Jember, untuk mengetahui kontribusi penerimaan pajak hotel terhadap penerimaan Pendapatan Asli Daerah (PAD) di Kabupaten Jember, dan untuk mengetahui kontribusi penerimaan pajak restoran terhadap penerimaan Pendapatan Asli Daerah (PAD) di Kabupaten Jember.

\section{Metode}

\section{Rancangan Penelitian}

Penelitian ini merupakan jenis penelitian kuantitatif dengan pendekatan deskriptif. Penelitian deskriptif merupakan penelitian nonhipotesis sehingga langkah penelitiannya tidak perlu merumuskan hipotesis (Arikunto dalam Pratama dkk., 2016:21).

\section{Jenis dan Sumber Data}

Jenis data yang digunakan dalam penelitian ini adalah data sekunder. Data sekunder yang digunakan dalam penelitian ini terdiri dari data target dan realisasi penerimaan pajak hotel, pajak restoran dan Pendapatan Asli Daerah (PAD) pada tahun 2011 sampai 2015 yang diperoleh dari Badan Pendapatan Daerah Kabupaten Jember berupa laporan realisasi penerimaan pendapatan daerah Kabupaten Jember.

\section{Metode Pengumpulan Data}

Dalam penelitian ini peneliti mengumpulkan data sekunder dengan metode dokumentasi yaitu pengumpulan data dari data-data yang ada dalam dokumen instansi terkait yaitu Badan Pendapatan Daerah Kabupaten Jember.

\section{Metode Analisis Data}

Metode penelitian yang digunakan peneliti dalam penulisan skripsi ini adalah metode deskriptif kuantitatif. Adapun langkah menganalisis datanya yang pertama mentukan tingkat efektivitas penerimaan pajak hotel dan pajak restoran, kedua menentukan kontribusi penerimaan pajak hotel dan pajak restoran dan yang ketiga melakukan pembahasan efektivitas dan kontribusi pajak hotel dan pajak restoran terhadap penerimaan Pendapatan Asli Daerah (PAD) dari tahun 2011 sampai tahun 2015 dalam bentuk deskriptif, tabel dan grafik. Untuk mentukan tingkat efektivitas penerimaan pajak hotel dan pajak restoran dilakukan dengan cara menyiapkan data target dan realisasi penerimaan pajak hotel dan pajak restoran, kemudian menghitung tingkat efektivitas penerimaan pajak hotel dan pajak restoran dengan menggunakan rumus rasio efektivitas (Halim, 2004:152), dan menentukan kategori tingkat efektivitas penerimaan pajak hotel dan pajak restoran dengan kriteria tingkat pencapaian diatas $100 \%$ berarti sangat efektif, tingkat pencapaian diantara $90-100 \%$ berarti efektif, tingkat pencapaian diantara $80-89 \%$ berarti cukup efektif, tingkat pencapaian diantara $70-79 \%$ berarti kurang efektif, tingkat pencapaian diantara $60-69 \%$ berati tidak efektif, dan tingkat pencapaian kurang dari $60 \%$ berarti sangat tidak efektif (Pratama dkk., 2016). Untuk menentukan kontribusi penerimaan pajak hotel dan pajak restoran dilakukan dengan cara menyiapkan data realisasi penerimaan pajak hotel, realisasi pajak restoran dan realisasi penerimaan Pendapatan Asli Daerah (PAD), menghitung kontribusi penerimaan pajak hotel dan pajak restoran terhadap penerimaan Pendapatan Asli Daerah (PAD), dan menentukan kategori kontribusi dengan kriteria kontribusi sebesar $80 \%-100 \%$ berarti besar sekali, kontribusi sebesar $60 \%-79 \%$ berarti besar, kontribusi sebesar 40\%-59\% berarti cukup besar, kontribusi sebesar 20\%-39\% berarti cukup dan kontribusi kurang dari $20 \%$ berarti kecil (Mahardika, 2015).

\section{Hasil dan Pembahasan}

\section{Hasil}

\section{Perhitungan Efektivitas Penerimaan Pajak Hotel}

Tingkat efektivitas pajak hotel dihitung dengan membandingkan realisasi penerimaan pajak hotel dengan target pajak hotel yang ditetapkan. Di bawah ini disajikan hasil perhitungan efektivitas pajak hotel Kabupaten Jember tahun 2011-2015 pada tabel 4.1 berikut:

Tabel 4.1 Efektivitas Penerimaan Pajak Hotel Kabupaten Jember Tahun 2011-2015

\begin{tabular}{ccccc}
\hline Tahun & $\begin{array}{c}\text { Target } \\
\text { Penerimaan } \\
\text { Pajak Hotel } \\
(\mathrm{Rp})\end{array}$ & $\begin{array}{c}\text { Realisasi } \\
\text { Penerimaan } \\
\text { Pajak Hotel } \\
(\mathrm{Rp})\end{array}$ & $\begin{array}{c}\text { Tingkat } \\
\text { Efektivitas } \\
(\%)\end{array}$ & Kategori \\
\hline 2011 & 1.100 .000 .000 & 1.258 .586 .574 & 114 & Sangat Efektif \\
2012 & 1.300 .000 .000 & 1.532 .424 .673 & 118 & Sangat Efektif \\
2013 & 1.450 .000 .000 & 2.125 .544 .285 & 147 & Sangat Efektif \\
2014 & 2.200 .000 .000 & 3.309 .254 .720 & 150 & Sangat Efektif \\
2015 & 2.720 .000 .000 & 3.520 .424 .646 & 129 & Sangat Efektif \\
\hline
\end{tabular}

Sumber: Laporan Realisasi Penerimaan Pendapatan Daerah Kabupaten Jember, Data Realisasi Penerimaan Pajak Hotel Kabupaten Jember Tahun 2011-2015, dan Data Diolah

Berdasarkan tabel di atas, terlihat pada tahun 2011 realisasi penerimaan pajak hotel sebesar Rp 1.258.586.574,00 dari target yang telah ditetapkan sebesar Rp 1.100.000.000,00. Maka diperoleh besarnya efektivitas penerimaan pajak hotel pada tahun 2011 sebesar 114\% yang berarti berada pada kategori sangat efektif. Pada tahun 2012, realisasi penerimaan pajak hotel sebesar Rp 1.532.424.673,00 dari target yang telah ditetapkan sebesar Rp 1.300.000.000,00. Maka diperoleh besarnya efektivitas penerimaan pajak hotel pada tahun 2012 sebesar $118 \%$ yang berarti berada pada kategori sangat efektif. Pada tahun 2013, realisasi penerimaan pajak hotel sebesar Rp 2.125.544.285,00 dari target yang ditetapkan sebesar Rp 1.450.000.000,00. Maka diperoleh besarnya efektivitas penerimaan pajak hotel pada tahun 2013 sebesar $147 \%$ yang berarti berada pada kategori sangat efektif. 
Kemudian pada tahun 2014, realisasi penerimaan pajak hotel sebesar Rp 3.309.254.720,00 dari target yang ditetapkan sebesar Rp 2.200.000.000,00. Maka diperoleh besarnya efektivitas penerimaan pajak hotel pada tahun 2014 sebesar $150 \%$ yang berarti berada pada kategori sangat efektif. Selanjutnya pada tahun 2015, realisasi penerimaan pajak hotel sebesar Rp 3.520.424.646,00 dari target yang ditetapkan sebesar Rp 2.720.000.000,00. Maka diperoleh besarnya efektivitas penerimaan pajak hotel pada tahun 2015 sebesar $129 \%$ yang berarti berada pada kategori sangat efektif.

\section{Perhitungan Efektivitas Penerimaan Pajak Restoran}

Tingkat efektivitas pajak restoran dihitung dengan membandingkan realisasi penerimaan pajak restoran dengan target pajak restoran yang ditetapkan. Dibawah ini disajikan hasil perhitungan efektivitas pajak restoran Kabupaten Jember tahun 2011-2015 pada tabel 4.2 berikut:

Tabel 4.2 Efektivitas Penerimaan Pajak Restoran Kabupaten Jember Tahun 2011-2015

\begin{tabular}{|c|c|c|c|c|}
\hline Tahun & $\begin{array}{c}\text { Target } \\
\text { Penerimaan } \\
\text { Pajak Hotel } \\
\text { (Rp) } \\
\end{array}$ & $\begin{array}{c}\text { Realisasi } \\
\text { Penerimaan } \\
\text { Pajak Restoran } \\
(\mathrm{Rp})\end{array}$ & $\begin{array}{c}\text { Tingkat } \\
\text { Efektivitas } \\
(\%)\end{array}$ & Kategori \\
\hline 2011 & 3.012 .419 .000 & 3.947 .655 .409 & 131 & $\begin{array}{l}\text { Sangat } \\
\text { Efektif }\end{array}$ \\
\hline 2012 & 3.500 .000 .000 & 4.755 .476 .643 & 136 & $\begin{array}{l}\text { Sangat } \\
\text { Efektif }\end{array}$ \\
\hline 2013 & 4.500 .000 .000 & 6.160 .556 .647 & 137 & $\begin{array}{l}\text { Sangat } \\
\text { Efektif }\end{array}$ \\
\hline 2014 & 5.500 .000 .000 & 7.557 .470 .425 & 137 & $\begin{array}{l}\text { Sangat } \\
\text { Efektif }\end{array}$ \\
\hline 2015 & 5.750 .000 .000 & 8.176 .884 .275 & 142 & $\begin{array}{l}\text { Sangat } \\
\text { Efektif }\end{array}$ \\
\hline
\end{tabular}

Sumber: Laporan Realisasi Penerimaan Pendapatan Daerah Kabupaten Jember, Data Realisasi Penerimaan Pajak Restoran Kabupaten Jember Tahun 2011-2015, dan Data Diolah

Berdasarkan tabel di atas, terlihat pada tahun 2011 realisasi penerimaan pajak restoran sebesar $\mathrm{Rp}$ 3.947.655.409,00 dari target yang ditetapkan sebesar Rp 3.012.419.000,00. Maka diperoleh besarnya efektivitas penerimaan pajak restoran tahun 2011 sebesar 131\%. Dengan begitu besarnya efektivitas penerimaan pajak restoran pada tahun 2011 berada pada kategori sangat efektif. Pada tahun 2012 realisasi penerimaan pajak restoran sebesar Rp4.755.476.643,00 dari target yang ditetapkan sebesar Rp3.500.000.000,00. Maka diperoleh besarnya efektivitas penerimaan pajak restoran tahun 2012 sebesar 136\% yang berarti berada pada kategori sangat efektif. Pada tahun 2013 realisasi penerimaan pajak restoran sebesar Rp6.160.556.647,00 dari target yang ditetapkan sebesar Rp4.500.000.000,00. Maka diperoleh besarnya efektivitas penerimaan pajak restoran sebesar $137 \%$ yang berarti berada pada kategori sangat efektif. Kemudian pada tahun 2014, realisasi penerimaan pajak restoran sebesar Rp7.557.470.425,00 dari target yang ditetapkan sebesar Rp5.500.000.000,00. Maka diperoleh besarnya efektivitas penerimaan pajak restoran tahun 2014 sebesar 137\% yang berarti berada pada kategori sangat efektif. Selanjutnya pada tahun 2015, realisasi penerimaan pajak restoran sebesar Rp8.176.884.275,00 dari target yang ditetapkan sebesar Rp5.750.000.000,00. Maka besarnya efektivitas penerimaan pajak restoran tahun 2015 sebesar $142 \%$ yang berarti efektivitas penerimaan pajak restoran berada dalam kategori sangat efektif.

\section{Perhitungan Kontribusi Penerimaan Pajak Hotel terhadap Penerimaan PAD}

Besarnya kontribusi penerimaan pajak hotel terhadap penerimaan PAD Kabupaten Jember dihitung dengan membandingkan realisasi penerimaan pajak hotel dengan realisasi penerimaan PAD. Di bawah ini disajikan hasil perhitungan kontribusi penerimaan pajak hotel terhadap penerimaan PAD Kabupaten Jember tahun 2011-2015 pada tabel 4.3 berikut:

Tabel 4.3 Kontribusi Penerimaan Pajak Hotel terhadap Penerimaan PAD Kabupaten Jember Tahun 2011-2015

\begin{tabular}{|c|c|c|c|c|}
\hline Tahun & $\begin{array}{c}\text { Realisasi } \\
\text { Penerimaan } \\
\text { Pajak Hotel } \\
\text { (Rp) }\end{array}$ & $\begin{array}{c}\text { Realisasi } \\
\text { Penerimaan PAD } \\
\text { (Rp) }\end{array}$ & $\begin{array}{c}\text { Tingkat } \\
\text { Efektivitas } \\
(\%)\end{array}$ & Kategori \\
\hline 2011 & 1.258 .586 .574 & $182.494 .390 .158,79$ & 0,69 & $\begin{array}{l}\text { Sangat } \\
\text { Efektif }\end{array}$ \\
\hline 2012 & 1.532 .424 .673 & $255.804 .775 .083,72$ & 0,6 & $\begin{array}{l}\text { Sangat } \\
\text { Efektif }\end{array}$ \\
\hline 2013 & 2.125 .544 .285 & $308.383 .350 .304,68$ & 0,69 & $\begin{array}{l}\text { Sangat } \\
\text { Efektif }\end{array}$ \\
\hline 2014 & 3.309 .254 .720 & $441.605 .617 .222,69$ & 0,75 & $\begin{array}{l}\text { Sangat } \\
\text { Efektif }\end{array}$ \\
\hline 2015 & 3.520 .424 .646 & $462.457 .671 .769,93$ & 0,76 & $\begin{array}{l}\text { Sangat } \\
\text { Efektif }\end{array}$ \\
\hline
\end{tabular}

Sumber: Laporan Realisasi Penerimaan Pendapatan Daerah Kabupaten Jember, Data Penerimaan PAD Kabupaten Jember dan Realisasi Penerimaan Pajak Hotel Tahun 2011-2015, dan Data Diolah

Berdasarkan tabel di atas terlihat, pada tahun 2011 realisasi penerimaan PAD sebesar Rp 182.494.390.158,79 dan besarnya realisasi penerimaan pajak hotel sebesar Rp1.258.586.574,00 sehingga diperoleh besarnya kontribusi penerimaan pajak hotel terhadap penerimaan PAD tahun 2011 sebesar 0,69\% yang berarti berada pada kategori kecil. Pada tahun 2012 realisasi penerimaan PAD sebesar Rp255.804.775.083,72 dan besarnya penerimaan pajak hotel sebesar Rp 1.532.424.673,00 sehingga diperoleh besarnya kontribusi penerimaan pajak hotel terhadap penerimaan PAD tahun 2012 sebesar 0,60\%. Dengan begitu besarnya kontribusi penerimaan pajak hotel terhadap penerimaan PAD tahun 2012 berada dalam kategori kecil. Pada tahun 2013 realisasi penerimaan PAD sebesar Rp308.383.350.304,68 dan besarnya penerimaan pajak hotel sebesar Rp 2.125.544.285,00 sehingga diperoleh besarnya kontribusi penerimaan pajak hotel terhadap penerimaan PAD tahun 2013 sebesar 0,69\% yang berarti berada dalam kategori kecil. Kemudian pada tahun 2014 realisasi penerimaan PAD sebesar Rp 441.605.617.222,69 dan besarnya penerimaan pajak hotel sebesar Rp3.309.254.720,00 sehingga diperoleh besarnya kontribusi penerimaan pajak hotel terhadap penerimaan PAD tahun 2014 sebesar 0,75\% yang berarti berada dalam kategori kecil. Selanjutnya, pada tahun 2015 realisasi penerimaan PAD sebesar Rp 462.457.671.769,93 dan besarnya realisasi penerimaan pajak hotel sebesar $\mathrm{Rp}$ 3.520.424.646,00 sehingga diperoleh besarnya kontribusi penerimaan pajak hotel terhadap penerimaan PAD tahun 2015 sebesar 0,76\%. Dengan begitu besarnya kontribusi 
penerimaan pajak hotel terhadap penerimaan PAD tahun 2015 berada dalam kategori kecil.

\section{Perhitungan Kontribusi Penerimaan Pajak Restoran terhadap Penerimaan PAD}

Besarnya kontribusi penerimaan pajak restoran terhadap penerimaan PAD Kabupaten Jember dihitung dengan membandingkan realisasi penerimaan pajak restoran dengan realisasi penerimaan PAD. Di bawah ini disajikan hasil perhitungan kontribusi penerimaan pajak restoran terhadap penerimaan PAD Kabupaten Jember tahun 2011-2015 pada tabel 4.4 berikut:

Tabel 4.4 Kontribusi Penerimaan Pajak Restoran terhadap Penerimaan PAD Kabupaten Jember Tahun 20112015

\begin{tabular}{|c|c|c|c|c|}
\hline Tahun & $\begin{array}{c}\text { Realisasi } \\
\text { Penerimaan } \\
\text { Pajak Restoran } \\
\text { (Rp) }\end{array}$ & $\begin{array}{l}\text { Realisasi Penerimaan } \\
\text { PAD (Rp) }\end{array}$ & $\begin{array}{l}\text { Tingkat } \\
\text { Efektivitas } \\
(\%)\end{array}$ & Kategori \\
\hline 2011 & 3.947 .655 .409 & $182.494 .390 .158,79$ & 2,16 & $\begin{array}{l}\text { Sangat } \\
\text { Efektif }\end{array}$ \\
\hline 2012 & 4.755 .476 .643 & $255.804 .775 .083,72$ & 1,86 & $\begin{array}{l}\text { Sangat } \\
\text { Efektif }\end{array}$ \\
\hline 2013 & 6.160 .556 .647 & $308.383 .350 .304,68$ & 2 & $\begin{array}{l}\text { Sangat } \\
\text { Efektif }\end{array}$ \\
\hline 2014 & 7.557 .470 .425 & $441.605 .617 .222,69$ & 1,71 & $\begin{array}{l}\text { Sangat } \\
\text { Efektif }\end{array}$ \\
\hline 2015 & 8.176 .884 .275 & $462.457 .671 .769,93$ & 1,77 & $\begin{array}{l}\text { Sangat } \\
\text { Efektif }\end{array}$ \\
\hline
\end{tabular}

Sumber: Laporan Realisasi Penerimaan Pendapatan Daerah Kabupaten Jember, Data Penerimaan PAD Kabupaten Jember dan Realisasi Penerimaan Pajak Restoran Tahun 2011-2015, dan Data Diolah

Berdasarkan tabel di atas terlihat, pada tahun 2011 realisasi penerimaan PAD sebesar Rp 182.494.390.158,79 dan besarnya realisasi penerimaan pajak restoran sebesar Rp3.947.655.409,00 sehingga diperoleh besarnya kontribusi penerimaan pajak restoran terhadap penerimaan PAD tahun 2011 sebesar 2,16\%. Dengan begitu besarnya kontribusi penerimaan pajak restoran terhadap penerimaan PAD tahun 2011 berada dalam kategori kecil. Pada tahun 2012 realisasi penerimaan PAD sebesar Rp 255.804.775.083,72 dan besarnya penerimaan pajak restoran sebesar Rp4.755.476.643,00 sehingga diperoleh besarnya kontribusi penerimaan pajak restoran terhadap penerimaan PAD tahun 2012 sebesar 1,86\% yang berarti berada dalam kategori kecil. Pada tahun 2013 realisasi penerimaan PAD sebesar Rp 308.383.350.304,68 dan besarnya penerimaan pajak restoran sebesar Rp 6.160.556.647,00 sehingga diperoleh besarnya kontribusi penerimaan pajak restoran terhadap penerimaan PAD tahun 2013 sebesar 2,00\% yang berarti berada dalam kategori kecil. Kemudian pada tahun 2014 realisasi penerimaan PAD sebesar Rp 441.605.617.222,69 dan besarnya penerimaan pajak restoran sebesar Rp7.557.470.425,00 sehingga diperoleh besarnya kontribusi penerimaan pajak restoran terhadap penerimaan PAD tahun 2014 sebesar 1,71\%. Dengan begitu besarnya kontribusi penerimaan pajak restoran terhadap penerimaan PAD tahun 2014 berada dalam kategori kecil. Selanjutnya, pada tahun 2015 realisasi penerimaan PAD sebesar Rp462.457.671.769,93 dan besarnya realisasi penerimaan pajak restoran sebesar $\mathrm{Rp} 8.176 .884 .275,00$ sehingga diperoleh besarnya kontribusi penerimaan pajak restoran terhadap penerimaan PAD tahun 2015 sebesar 1,77\% yang berarti berada dalam kategori kecil.

\section{Pembahasan}

\section{Efektivitas Penerimaan Pajak Hotel}

Efektivitas penerimaan pajak hotel menggambarkan hubungan antara realisasi dan target penerimaan pajak hotel. Tingkat efektivitas disini dapat memperlihatkan kemampuan pemerintah daerah dalam merealisasikan pajak hotel yang telah ditargetkan sebelumnya. Hasil penelitian menunjukkan secara keseluruhan efektivitas penerimaan pajak hotel Kabupaten Jember selama lima tahun yaitu tahun 2011 sampai 2015 berada dalam kategori sangat efektif karena tingkat efektivitasnya di atas $100 \%$. Tingkat efektivitas penerimaan pajak hotel pada tahun 2011 sampai 2014 selalu mengalami peningkatan. Hal ini dikarenakan realisasi penerimaannya selalu meningkat setiap tahunnya. Pada tahun 2011 tingkat efektivitas penerimaan pajak hotel sebesar 114\% dengan realisasi penerimaan sebesar $\mathrm{Rp} 1.258 .586 .547,00$ kemudian pada tahun 2012 tingkat efektivitasnya mengalami peningkatan menjadi sebesar $118 \%$ dengan realisasi penerimaan pada tahun 2012 yang lebih besar dari tahun sebelumnya, realisasi penerimaan pajak hotel pada tahun 2012 sebesar Rp 1.532.424.673,00. Selanjutnya, pada tahun 2013 tingkat efektivitas penerimaan pajak hotel meningkat lagi menjadi sebesar $147 \%$ dengan realisasi penerimaan sebesar Rp 2.125.544.285,00 yang mengalami peningkatan dari realisasi tahun sebelumnya dan pada tahun 2014 tingkat efektivitasnya meningkat lagi menjadi sebesar $150 \%$ dengan realisasi yang lebih besar lagi sebesar Rp 3.309.254.720,00. Pada tahun 2015 tingkat efektivitas penerimaan pajak hotel mengalami penurunan dari tahun sebelumnya. Tingkat efektivitas penerimaan pajak hotel pada tahun 2015 hanya sebesar $129 \%$. Penurunan persentase efektivitas pada tahun 2015 ini dikarenakan semakin besarnya target penerimaan yang ditetapkan dan realisasi penerimaan pada tahun 2015 tidak terlalu jauh melebihi target penerimaan seperti pada tahun-tahun sebelumnya. Walaupun pada tahun 2015 tingkat efektivitasnya mengalami penurunan dari segi persentase, tetapi masih dalam kategori sangat efektif. Selain itu, jika dilihat dari nominal realisasi penerimaannya pada tahun 2015 lebih besar dari realisasi penerimaan tahun-tahun sebelumnya, realisasi penerimaan pada tahun 2015 sebesar Rp 3.520.424.646,00. Secara keseluruhan, berdasarkan hasil perhitungan tingkat efektivitas penerimaan pajak hotel menunjukkan bahwa pemerintah daerah Kabupaten Jember telah berhasil dalam mencapai target penerimaan pajak hotel yang telah ditetapkan.

\section{Efektivitas Penerimaan Pajak Restoran}

Efektivitas penerimaan pajak restoran menggambarkan hubungan antara realisasi dan target penerimaan pajak restoran. Tingkat efektivitas disini dapat memperlihatkan kemampuan pemerintah daerah dalam merealisasikan pajak restoran yang telah ditargetkan sebelumnya. Hasil penelitian menunjukkan bahwa efektivitas penerimaan pajak restoran Kabupaten Jember selama tahun 2011 sampai 2015 berada dalam kategori sangat efektif karena tingkat efektivitasnya di atas $100 \%$. Tingkat efektivitas penerimaan pajak restoran selama tahun 2011 sampai 2015 selalu mengalami peningkatan. Hal ini dikarenakan realisasi penerimaan pajak 
restoran yang semakin meningkat setiap tahunnya walaupun targetnya juga selalu ditingkatkan. Tingkat efektivitas penerimaan pajak restoran pada tahun 2011 sebesar 131\% dengan realisasi sebesar Rp 3.947.655.409,00 kemudian pada tahun 2012 tingkat efektivitasnya meningkat menjadi sebesar $136 \%$ dengan realisasi penerimaan pajak restoran pada tahun 2012 lebih besar dari realisasi penerimaan tahun sebelumnya, realisasi penerimaan pajak restoran pada tahun 2012 sebesar Rp 4.755.476.643,00. Selanjutnya, pada tahun 2013 tingkat efektivitas penerimaan pajak restoran meningkat lagi menjadi sebesar 137\% dengan realisasi sebesar Rp 6.160.556.647,00. Kemudian, pada tahun 2014 tingkat efektivitas penerimaan pajak restoran sebesar $137 \%$ sama dengan tingkat efektivitas tahun sebelumnya tetapi realisasi penerimaannya lebih besar dari tahun sebelumnya, realisasi penerimaan pada tahun 2014 sebesar Rp7.557.470.425,00. Kemudian pada tahun 2015 tingkat efektivitasnya meningkat lagi menjadi sebesar 142\% dengan realisasi penerimaan sebesar Rp 8.176.884.275,00. Secara keseluruhan, berdasarkan hasil perhitungan tingkat efektivitas penerimaan pajak restoran menunjukkan bahwa pemerintah daerah Kabupaten Jember telah berhasil dalam mencapai target penerimaan pajak restoran yang telah ditetapkan.

\section{Kontribusi Penerimaan Pajak Hotel terhadap Penerimaan PAD}

Kontribusi penerimaan pajak hotel terhadap penerimaan PAD menggambarkan seberapa besar proporsi penerimaan pajak hotel terhadap penerimaan PAD. Hasil penelitian menunjukkan bahwa secara keseluruhan kontribusi penerimaan pajak hotel pada tahun 2011 sampai 2015 terhitung kecil terhadap penerimaan PAD Kabupaten Jember karena persentase kontribusi tiap tahunnya kurang dari 20\%. Hal ini berarti bahwa proporsi pajak hotel kecil terhadap penerimaan PAD Kabupaten Jember. Pada tahun 2011 kontribusi penerimaan pajak hotel terhadap penerimaan PAD Kabupaten Jember sebesar 0,69\% dari realisasi penerimaan PAD sebesar Rp 255.804.775.083,72. Kemudian, pada tahun 2012 kontribusi penerimaan pajak hotel terhadap penerimaan PAD Kabupaten Jember menurun dari tahun sebelumnya menjadi sebesar 0,60\% dari realisai penerimaan PAD sebesar Rp 182.494.390.158,79. Walaupun persentase kontribusinya mengalami penurunan tetapi nominal realisasi penerimaan pajak hotel pada tahun 2012 sebesar Rp 1.532.424.673,00 dari total hotel sebanyak 40 lebih besar dari realisasi penerimaan tahun 2011 yang hanya sebesar $\mathrm{Rp}$ 1.258.586.574,00 dari total hotel sebanyak 36 namun peningkatan realisasi penerimaan pajak hotel tidak sebanding dengan peningkatan realisasi penerimaan PAD nya sehingga mengakibatkan penurunan persentase kontribusi penerimaan pajak hotel terhadap penerimaan PAD. Kemudian, pada tahun 2013 kontribusinya meningkat menjadi sebesar $0,69 \%$ dari realisasi penerimaan PAD sebesar Rp 308.383.350.304,68. Pada tahun ini realisasi penerimaan pajak hotel meningkat dari tahun sebelumnya menjadi sebesar Rp 2.125.544.285,00 dari total hotel sebanyak 43. Selanjutnya, pada tahun 2014 kontribusinya meningkat lagi menjadi sebesar $0,75 \%$ dari penerimaan PAD sebesar Rp 441.605.617.222,69. Pada tahun 2014 ini realisasi penerimaan pajak hotel meningkat dari tahun sebelumnya menjadi $\mathrm{Rp} 3.309 .254 .720,00$ dari total hotel sebanyak 45. Pada tahun 2015 kontribusinya meningkat menjadi sebesar $0,76 \%$ dari penerimaan PAD sebesar Rp462.457.671.769,93. Pada tahun ini realisasi penerimaan pajak hotel mengalami peningkatan lagi menjadi Rp3.520.424.646,00 dari total hotel sebanyak 46.

\section{Kontribusi Penerimaan Pajak Restoran terhadap Penerimaan PAD}

Kontribusi penerimaan pajak restoran terhadap penerimaan PAD menggambarkan seberapa besar proporsi penerimaan pajak restoran terhadap penerimaan PAD. Hasil penelitian menunjukkan bahwa kontribusi penerimaan pajak restoran selama lima tahun yaitu tahun 2011 sampai 2015 terhitung kecil terhadap penerimaan PAD Kabupaten Jember karena persentase kontribusi tiap tahunnya kurang dari $20 \%$. Hal ini berarti bahwa proporsi pajak restoran kecil terhadap penerimaan PAD Kabupaten Jember. Kontribusi penerimaan pajak restoran terhadap PAD Kabupaten Jember pada tahun 2011 sebesar 2,16\% dari penerimaan PAD sebesar Rp182.494.390.158,79. Pada tahun ini realisasi penerimaan pajak restoran sebesar $\mathrm{Rp} 3.947 .655 .409,00$ dari jumlah restoran sebanyak 163. Kemudian, pada tahun 2012 kontribusinya turun menjadi $1,86 \%$ dari penerimaan PAD sebesar Rp 255.804.775.083,72. Meskipun persentase kontribusinya turun tetapi nominal realisasi penerimaan pajak restoran pada tahun 2012 naik menjadi sebesar Rp4.755.476. 643,00 dari jumlah restoran sebanyak 174. Pada tahun 2013 kontribusi penerimaan pajak restoran terhadap PAD Kabupaten Jember terjadi peningkatan menjadi sebesar 2,00\% dari penerimaan PAD sebesar Rp308.383.350.394,68. Pada tahun ini realisasi penerimaan pajak restoran meningkat lagi menjadi sebesar Rp6.160.556.647,00 dari jumlah restoran sebanyak 189. Kemudian, pada tahun 2014 kontribusinya turun menjadi menjadi $1,71 \%$ dari penerimaan PAD sebesar Rp441.695.617.222,69. Walaupun persentase kontribusinya turun tetapi nominal realisasi penerimaan pajak restoran pada tahun 2014 naik menjadi sebesar menjadi Rp7.557.470.425,00 dari jumlah restoran sebanyak 202. Pada tahun 2015 kontribusi penerimaan pajak restoran terhadap PAD Kabupaten Jember terjadi peningkatan menjadi sebesar 1,77\% dari penerimaan PAD sebesar Rp462.457.671.769,93. Pada tahun ini realisasi penerimaan pajak restoran terjadi peningkatan lagi menjadi sebesar Rp8.176.884.275,00 dari jumlah restoran sebanyak 212. Meskipun realisasi penerimaan pajak restoran selama tahun 2011 sampai 2015 selalu mengalami peningkatan setiap tahunnya namun persentase kontribusinya terhadap PAD tidak selalu mengalami peningkatan hal ini dikarenakan peningkatan penerimaan pajak restoran tidak sebanding dengan peningkatan penerimaan PAD-nya karena penerimaan PAD tidak hanya bersumber dari pajak restoran saja tetapi dari pajak daerah, restribusi daerah, hasil pengelolaan kekayaan daerah yang dipisahkan dan lain-lain PAD yang sah.

\section{Simpulan}

Berdasarkan pemaparan hasil dan pembahasan, maka dapat disimpulkan tingkat efektivitas penerimaan pajak hotel Kabupaten Jember selama tahun 2011 sampai 2015 berada dalam kategori sangat efektif karena persentase tingkat efektivitas setiap tahunnya di atas $100 \%$. Tingkat efektivitas penerimaan pajak hotel Kabupaten Jember selama lima tahun berturut-turut sebesar $114 \%$ pada tahun 2011, 118\% pada tahun $2012,147 \%$ pada tahun $2013,150 \%$ pada tahun 2014 , dan $129 \%$ pada tahun 2015 . Kemudian, tingkat efektivitas penerimaan pajak restoran Kabupaten Jember selama tahun 
2011 sampai 2015 berada dalam kategori sangat efektif karena persentase tingkat efektivitas setiap tahunnya di atas $100 \%$. Tingkat efektivitas penerimaan pajak restoran Kabupaten Jember berturut-turut sebesar 131\% pada tahun $2011,136 \%$ pada tahun $2012,137 \%$ pada tahun $2013,137 \%$ pada tahun 2014 , dan $142 \%$ pada tahun 2015 . Kontribusi penerimaan pajak hotel selama tahun 2011 sampai 2015 terhitung kecil terhadap penerimaan Pendapatan Asli Daerah (PAD) Kabupaten Jember karena persentase kontribusi tiap tahunnya kurang dari $20 \%$. Kontribusi penerimaan pajak hotel terhadap penerimaan Pendapatan Asli Daerah (PAD) Kabupaten Jember berturut-turut sebesar $0,69 \%$ pada tahun $2011,0,6 \%$ pada tahun $2012,0,69 \%$ pada tahun $2013,0,75 \%$ pada tahun 2014 dan $0,76 \%$ pada tahun 2015 . Kemudian, kontribusi penerimaan pajak restoran selama tahun 2011 sampai 2015 terhitung kecil terhadap penerimaan Pendapatan Asli Daerah (PAD) Kabupaten Jember karena persentase kontribusi tiap tahunnya kurang dari 20\%. Kontribusi penerimaan pajak restoran dalam penerimaan Pendapatan Asli Daerah (PAD) Kabupaten Jember selama tahun 2011 sampai 2015 berturut-turut sebesar 2,16\% pada tahun 2011, $1,86 \%$ pada tahun $2012,2 \%$ pada tahun $2013,1,71 \%$ pada tahun 2014, dan 1,77\% pada tahun 2015 .

\section{Referensi}

Halim, A. 2004. Akuntansi Keuangan Daerah. Jakarta: Salemba Empat.

Pratama, R. P., M. Saifi, dan Z. ZA. 2016. Efektivitas Penerimaan Pajak Restoran dalam Meningkatkan Pendapatan Asli Daerah (Studi pada Dinas Pendapatan Daerah Kabupaten Kediri). Jurnal Administrasi Bisnis. 30(1).

Undang-Undang Republik Indonesia Nomor 28 Tahun 2009. Pajak Daerah dan Retribusi Daerah. 15 September 2009. Lembaran Negara Republik Indonesia Tahun 2009 Nomor 130.Jakarta.

Undang-Undang Republik Indonesia Nomor 32 Tahun 2004. Pemerintah Daerah. 15 Oktober 2004. Lembaran Negara Republik Indonesia Tahun 2004 Nomor 125. Jakarta.

www.sindoweekly.com [diakses tanggal 12 Oktober 2016] 